\title{
ヴィオレ・ル・デュクによるトゥルーズのサン・セルナン 教会堂の修復について \\ ON THE RESTORATION OF SAINT SERNIN CHURCH OF TOULOUSE BY VIOLLET LE DUC
}

\author{
羽生修二* \\ Shuï HANYU
}

\begin{abstract}
The restoration of the cresting and roofing of Saint Sernin Church in Toulouse is at the heart of an important debate today, since it is difficult to maintain the elements conceived and realized by Viollet le Duc between 1860 and 1879.

The High Commission for Historic Monuments decided for the return to the state before 1860, since Viollet le Duc's restoration was not based on the incontestable archeological evidence.

The present paper deals with the relationship between theory and practice in his restoration works of Saint Sernin Church.
\end{abstract}

Keywords : Viollet le Duc, restoration, restitution, Saint Sernin Church of Toulouse ヴィオレ・ル・デュク, 修復, 復原, トゥルーズのサン・セルナン教会堂

1. 序

フランス・ロマネスクの建築遺構で最大規模を誇る トゥルーズのサン・セルナン教会堂 (Église de Saint Sernin de Toulouse) は, サンチャゴ・デ・コンポステ ラ (Santiago de Compostela) への巡礼路に沿って立 てられた，典型的巡礼路教会堂である。しかし，現在の 姿は 19 世紀の修復によって大幅に形状が変更されてい る。とくに屋根と軒廻りの形式は, 当初のものではなく, 修復を担当したウジェーヌ・エマニュエル・ヴィオレ・ ル・デュク (Eugène Emmanuel VIOLLET-LE-DUC, 1814-1879) の創作なのである。それゆえヴィオレ・ル・ デュクの修復に対する非難の声は，工事がまだ完了しな い1874 年にはすでに起きている。たとえば南部考古学 会 (Société Archéologique du Midi de la France) の キャリエール修院長 (Abbé M. B. CARRIÈRE) は, 「この記念物でもっとも貴重な後陣部分の現在の姿は, 会場に来た観衆全員に非難と惜念の気持ちを抱加せる演 奏会を催したようなものだ」”とし，後陣部分の復原を 嘆いている。そして, ヴィオレ・ル・デュク没後百周年 に当たる 1980 年 ${ }^{2} に は$, 現在のサン・セルナン教会堂 の主任建築家であるイヴ・ボワレ (Yves BOIRET) か ら「ヴィオレ・ル・デュクの修復を修復する」計画案が 提示された。ボワレの報告によれば，19世紀の修復で
大がかりな形状の変更がなされた, 屋根部分の損傷が今 日甚大となり，緊急に修復しなければならない状態にあ る。そのために次の二者択一が迫られているというので ある。つまりヴィオレ・ル・デュクの修復を歴史の一様 相として尊重し保存するか, または 19 世紀の修復を放 棄し, ヴィオレ・ル・デュクの介入以前の姿に復原する か, よ゙ちらかを選ばなければならない所まで来ているの である(図一1)。

そして 1990 年 6 月 6 日歴史的記念物上級委員会 (Commission supérieure des Monuments historiques) は, ヴィオレ・ル・デュクの復原には考古学的裏付けがない と判断し, ヴィオレ・ル・デュク以前の状態に復原する ことを承認したのである゙่。

本稿は今日再び修復が行わなければならない状況にあ るトゥルーズのサン・セルナン教会堂において, ヴィオ レ・ル・デュクがいかなる理論で修復を行ったか検討 し4), ヴィオレ・ル・デュクの建築理論との関係を考察 しようとするものである。

\section{2. サン・セルナン教会堂の沿革}

トゥルーズのサン・セルナン教会堂の創建は，トゥ ルーズ教区の初代司教だった殉教聖人サチュルナン (Saint Saturnin) の聖遺物を奉納するマルテイリウム 
として 4 世紀後半に建設されたことから始まったといわ れている5!。最初の建物は，木造の簡素なものであり， 聖遺物を納める所だけ煉瓦のヴォールト天井が架けられ ていた。敷地は現在の所とは異なり, 今日のノートル・ ダム・デュ・トール教会堂 (Église de Notre Dame du Taur）が立っている場所だった。聖サチュルナンの人 気は, 当時からかなりのものがあったらしく, 巡礼が後 を絶たない状態だったらしい。そのため最初に建てられ た小さなマルティリウムだけでは手狭になったので，5 世紀になって現在の敷地に聖遺物を移して新しい教会堂 を建設する。しかしこの教会堂もやがてサラセン人によ る破壊やシャルルマーニュの再建, そして再び破壊と いった繰り返しを経る。そして，11世紀に入り世の中 が安定するにつれて, 現在のような大規模な教会堂建設 の計画が立てられる。この計画は, 1018 年から 1032 年 まで在位したピェール・ロジェ司教 (Evêque Pierre ROGER) が中心になって進められ，1080 年頃によう やくサン・セルナン教会堂再建の工事が始まる。そして 1096 年 5 月 24 日ローマ教皇ウルバヌス II 世 (Pape Urbain II）によって内陣の献堂式が行われる。これが 現在のサン・セルナン教会堂の最も古い部分である。内 陣部分に続いて 1118 年には外陣の側廊が完成し, 身鿾 も高空の位置まで立ち上がっていた。そして 12 世紀半 ばには，内陣の回りを一巡する周歩廊やそこに放射状に 並ぶ祭室, トランセプト, 交差部上の鐘塔などもおおよ そ完成する。鐘塔は 13 世紀後半になって増築され，3 層から 5 層になる。この増筑工事で鐘塔の巨大な重量を 支えるために交差部の 4 本のピアが補強され，身瑯から 内陣に向かう視界が狭くなっている。そのために身廊か ら内陣へのパースペクティヴな効果が当初と比べて減少 している。

このような経過を経てサン・セルナン教会堂は, 14 世紀初めには全体がほぼ完成するのだが，宗教戦争の開 始と共に変容する。1562 年 5 月 12 日カルヴァン派が教 会を占拠し，要塞として使用するために改造を行う。側

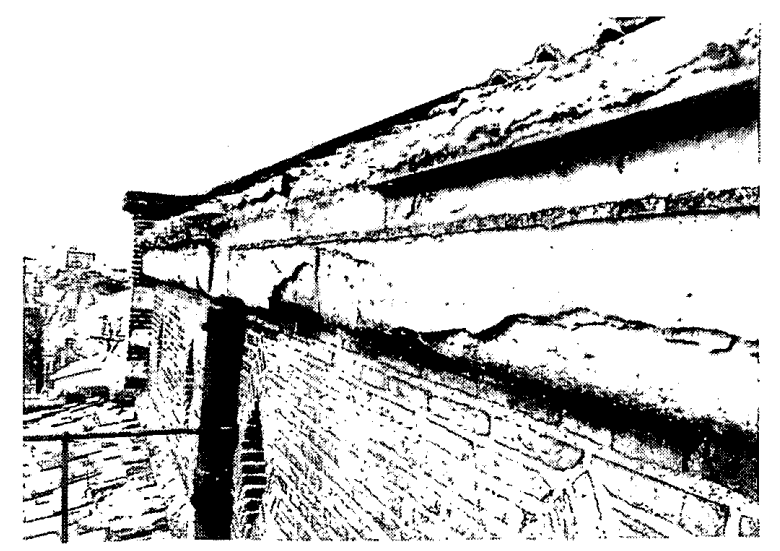

図一1 ヴィオレ・ル・デュクによって創設された軒先の破損状 況
壁を増築し，そこに半円アーチの小空を開け，大砲の砲 身を出す銃眼にしたのである6!。しかしそれ以外は大き な改造を加えられることもなく，またフランス大革命に よる大がかりな破壊も受けなかった。それは、この教会 堂がトゥルーズで最も古く重要な建物であり, そのうえ 市民の聖サチュルナンへの根強い信仰があったからに他 ならなかった。それゆえ1834 年に歴史的記念物総監プ ロスペル・メリメ (Prosper MÉRIMÉE, 1803-1870) がサン・セルナン教会堂を視察した際, 保存の上で緊迫 した状況にはまったくなかっだ!。

1837 年メリメの推薦によって, サン・セルナン教会 堂は，歴史的記念物 (Monuments historiques) に指定 され，国の補助を受けて保護されることになる。それに 答えてトゥルーズ市側も独自の教会堂周辺の整倩を開始 する。それはメリメが「あいにく右のトランセプトの外 側に，近代になって増築された聖具室がこのグループの さまざまな部分の調和や秩序を破り，その総合的効果を いささか損なっている」五と『南仏紀行』(Notes de Voyages) で記したことに対するものだった。トゥルー ズ市は教会堂に寄り添うように増築された建物を撤去 し，サン・セルナン教会堂の外観をより美しく兒せるた めに周りを広場にした。それに続いて教会堂の外観の復 原が行われることとなる。メリメは，この工事をヴェズ レーのラ・マドレーヌ教会堂の修復で初めて登用した ヴィオレ・ル・デュクに依頼するよう，歴史的記念物姿 員会に推薦した。

「サン・セルナンほよ゙の素晴らしい記念物を, 熟練し た，経験豊富な芸術家以外に任せられないし，任せては ならない。報告者はヴィオレ・ル・デュク氏に依頼する よう提案する $j^{91}$

そして, 1845 年 4 月 18 日, 歴史的記念物委員会の決 定が下され，ヴィオレ・ル・デュクがトゥルーズのサ ン・セルナン教会堂の修復計画を担当することよなる。

\section{3. ヴィオレ・ル・デュクによる修復工事}

ヴィオレ・ル・デュクの修復計画は 1847 年 1 月 31 日 に歴史的記念物委員会に提出された。メリメはこの修復 計画案を評洒し,

「ル・デュク氏の計画案はたいへん結構だと思う。ま ずこの記念物でもっとも美しい後陣から着手し, 後陣の 室内と外壁を完全に復原する。それから時間と予算が 整ったら，残りを修復するというものである。最優先す ベきことは，それ自身醜悪であり，ヴォールトにとって も嘆かわしい屋根形式を変えることである」101

と述べている。その時同時に提出された見積書と報告書 には修復費用として，574222 フラン必要だとし，大部 分は屋根形式の大がかりな変更に当てられていた。しか し市の財政困難と 1848 年の革命勃発なよ゙の事情ですぐ 
に予算が下りず，工事開始は1860 年まで待たなければ ならなかった。

修復工事の内容については，ヴィオレ・ル・デュクを 補佐して現場監理を行っていた地元の建築家，J. エス キエ (J.ESQUIÉ) $)^{11 \prime}$ が詳細な記録 ${ }^{12)}$ を残している。こ こでは，それを基に工事の経過を辿ってみる。 1860 年

10 月 22 日 修復工事開始。

10-11月 モルタルで覆い隠された放射状祭室，後 陣，卜ランセプト東面の外壁をはつって 石と煉瓦の石組をよみがえらせる。

南側袖廊の祭室間に増築された聖具室 2 室を取り壊す。なぜなら，「これらの聖 具室は美術的価值がまったくなく，後陣 の注目すべき部分を不愉快に覆い隠して いたから」洨。

聖具室の除去工事の際，ロマネスクのク リプトがその下にあったことが発見さ れ，それを保護するためにコンクリート の防水層をその上に設ける。 バットレスの解体と再建。

1861 年 後陣とトランセプト祭室の外壁基部にお ける石組の入れ替え。その際に当初材の ボケール石 (pierre de Beaucaire) だけ ではなく, カルカソンヌ石 (pierre de Carcassonne) も採用する。 祭室の屋根を石の板瓦に莫替える。

1861 年末 .バットレス 2 箇所と祭室 9 室の外壁基部 の修復完了。

南トランセプトと後陣の祭室のコーナー のバットレスが全体的に再建される。 地面と第一層目のコーニスとの間に入っ ている崃瓦層の修復と目地の塗直し。 サン・テスプリの祭室 (chapelle SaintEsprit) の屋根を石㯰で完了。 サン・シールとサント・ジュリットの祭

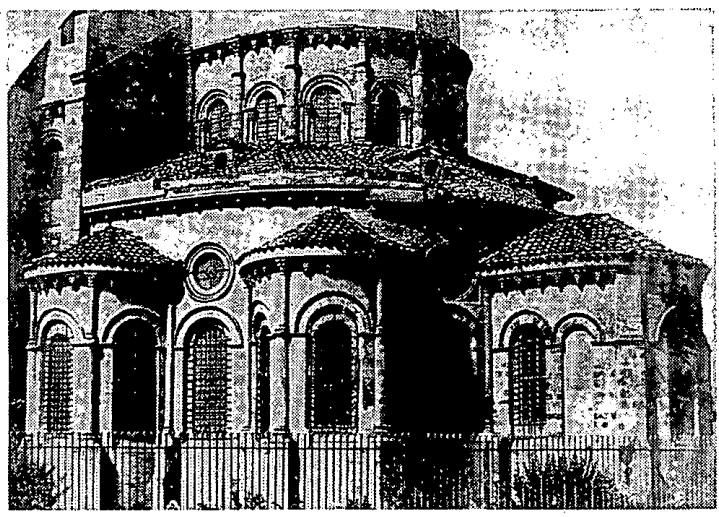

図一2 1860 年以前の後陣部分
室 (chapelle Saint-Cyr et Sainte-Juliette）の屋根を半分だけ石莫に替える。 持送りを彫刻する。

ヴィオレ・ル・デュクが後陣雨樋のガル グイユの図面を作成するようエスキエに 依頼する。

1862 年 後陣と祭室の半円蓋状ヴォールトに石の 平瓦を莫く（図一2, 図一 3 )。 祭室の室内修纉とそこに飾られた金箔塗 飾り壁の撤去。

1862 年 5 月 鐘塔修復のための「かなり複雑な」支保 工の建設。

トランセプト北の 16 世紀に増築された 屋根部分の取り壊し開始。

1863 年鐘塔屋根の修復完了。

トランセプト北の屋根部分の再建。

トランセプト南の屋根部分の再建開始。

鐘塔ピアの補強工事。

ストライキによる工事の遅延。

1863 年末 トランセプト北の工事完了。

トランセプト西側に立つ小塔の屋根葺工

事。

1864 年

6 月 19 日 ヴィオレ・ル・デュクは, 大臣に予算の 第一期分の工事が終了したことを報告し ている。そこで鐘塔の修復にかかった 24000 フランの予算超過分が追加され た。

1865-1869 年 工事は 1865 年末大幅に遅延する。そし て身廊の修復は1869 年突然中止となる。 その理由は第二期工事用にあった予算 （182000フラン）が屋根の新しい形式 を再建している途中で使い果たしてし まったからである。そのために北側身廊 の屋根は剝かれたままになる。それは 1847 年に作成され，1860年に訂正され

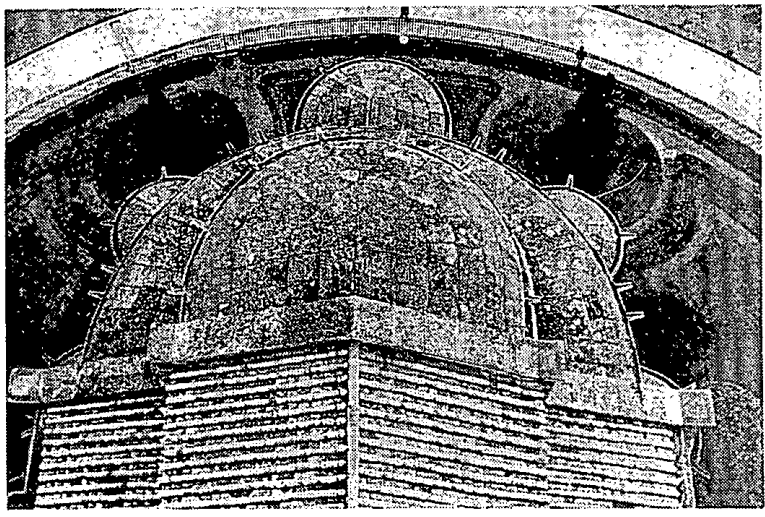

図一3石苜に変更された後陣部分屋根: 
たヴィオレ・ル・デュクの見積額が, 南 仏鉄道のストによる1860～1862 年の手 間貨・材料費高騰で大きく超過したため である14)。しかし，辛うじて $50000 フ ラ$ ンの予算が市と国（1870 年 6 月 2 日付） で認められる。

1870 年

7 月 15 日 戦争が勃発し, 工事が中断される。 1872 年 12 月 身鄉北側部分の屋根工事が特別予算を 使って完了。

1874-1878 年 補正予算によって, 北側身廊の敷石と装 飾の工事開始。南側のルネサンス門，トゥ ルーズ伯墳墓の小穴，南北トランセプト の扉口の工事。

1878 年末 ステンド・グラス, 家具, 祭壇などの修 復計画が練られる。

1879 年

9 月 17 日 ヴィオレ・ル・デュク没す。工事の終章

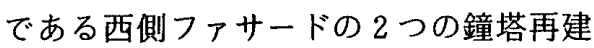
は，とうとう着手せずに終わる.(図一4, 図一5)。最終的にトゥルーズのサン・セル ナン教会堂の修復工事は, 合計 787600 フランに達した。

\section{4. ヴィオレ・ル・デュクによる形状の変更}

\section{1) 交換材の選択 ${ }^{15)}$}

トゥルーズのサン・セルナン教会堂において, 当初か ら用いられていた材料は，プロヴァンス地方で産出され るボケールの石灰岩だった。しかしヴィオレ・ル・デュ クはバットレス，外壁そして軒廻りに使われた石の交換 材として「より強固な」カルカンンヌの石 ${ }^{16)}$ を採用した。 ところが，「より上質な材料」と見えたカルカソン又石 の選択には大きな誤りがあった。現在サン・セルナン教 会堂の修復を担当しているイヴ・ボワレによれば"77, 次 の3点において問題が生じている。

(1) 選ばれたカルカソンヌ石の色調は, 当初のものとは 大変異なり，そのうえ石目も全然違う。そのために外観

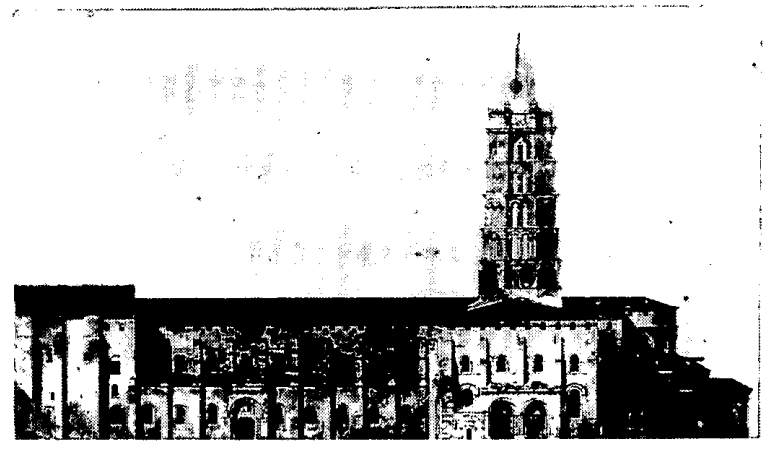

図一4 修復前の南立面図（ヴィオレ・ル・デュクによる）
の調和が乱された。

(2) 柔らかい石の上に堅い石を積み重ねることは, 保存 すべき昔からの石組の腐食を促進させる原因となった。

(3) カルカソンヌの砂岩は, ヴィオレ・ル・デュクが 思っていたほど堅固な石ではなく，今日では欠陷のある 材料と見なされている。現に，カルカソンヌ石は層面に 沿って剥離しやすく，すぐ粉々になってしまう尔陥があ る。そのために, 雨樋が破損・佚し, 雨水が壁面に浸 透する結果となった。

ところで，ヴィオレ・ル・デュクはなぜこのような譟 ちを犯したのであろうか。その理由として第一に上げら れるのは，多くの人々によって指摘されたように年，北 フランスを中心に仕事をしてきたヴィオレ・ル・デュク は南フランスの材料に関する知識に久けていたというこ とである。現場を実際に監督していたのは，地元の建築 家エスキエでありヴィオレ・ル・デュク自身はフランス 全土の歴史的記念物の修復現場を巡察するのに追われて いた。そんな状況の中で，一地方の材料に関してそれに ど染い知識を持っていなかったに違いない。しかし当時 のトゥルーズに，もし適格な助言を与えることのできる 建築家や考古学者がいたならば，このような間違いは起 きなかったであろう。さらに，上で見てきたように，サ ン・セルナン教会堂修復の補助金が停滞し，南伿鉄道の 買占め，ストなどで運搬費，材料費，人件費が㩧騰して いる状況で，わざわざプロヴァンス地方のボケールから 材料を調達するのは予算の関係で困難だった可能性もあ る。しかし，いずれにしてもヴィオレ・ル・デュクが交 換材の選択を誤ったことは事実なのである。

2). 目 地

外観ファサードの様相を変えたもう一つの原因は, 石 目地の塗直しによるものであった。石造建築の目地とい うのは，ファサードの表情に大きな影響を及ぼすばかり ではなく，目塗りの方法によって時代判定や地方性を判 別することが出来るほどにデリケートな要素なのであ る。ヴィオレ・ル・デュクによって実施された目地の塗 直しは，あまりに画一的であり，しかも北フランスの建 築の目地のように, 極端に浮き出した仕上げにしている。

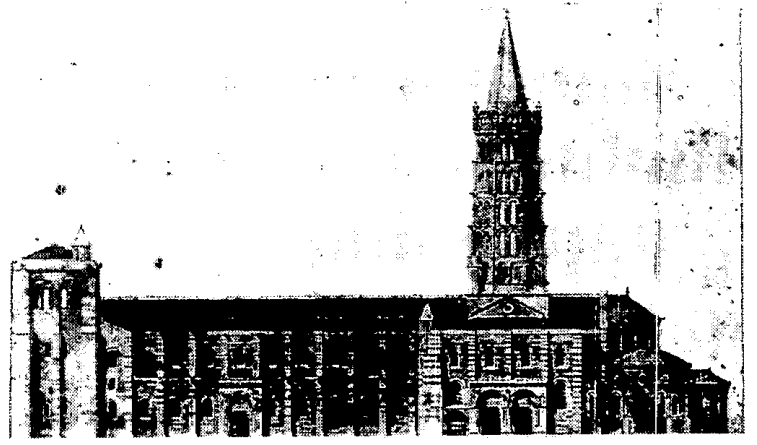

図一5 ヴィオレ・ル・デュクによる南立面の修復計画案 
この方法は雨の多い地方では㔀がれ安く,不適切である。 その上，目地の多様性によって見ることができた歴史的 痕跡をすべて覆い隠してしまい，歴史的事実に対して痛 徹な，「冷たい修復」の印象を強く与えることになった。 3）屋根部分の復原 ${ }^{191}$

ヴィオレ・ル・宁ュクによるサン・セルナン教会堂の 修復において，最も大きな問題となったのは; 屋根の復 原についてである。つまり後陣と放射状祭室の屋根草材 料を丸瓦から石の平瓦に変更したこと，そして 16 世紀 頃に増築されたと考えられる側壁を取壊し，身廊とトラ ンセプトに新しい屋根形式を与えたことである（図一6, 図-7)。

まず後陣部分の屋根を石莫に変えたことに関しては， ヴィオレ・ル・デュクが修復計画を構想する以前に, 地 元の南部考古学会がすでに石の平瓦蒀に変更するよう提 案していた ${ }^{20)}$ 。それゆえヴィオレ・ル・デュクは地元の 考古学会の意見に従って, 屋根葺材の変更を計画したわ けである。しかし皮肉にも30 年後に同じ考古学会の会 員が，この石莫屋根を非難することとなる21!。ところで, こうした地元の考古学者の意見とは別にヴィオレ・ル・ デュク自身も石の平瓦をヴォールトの上に莫くことは適 切だと考えていた。るれは『中世建築事典』(Dictionnaire raisonné de l'Architecture française du XIème au XVIème

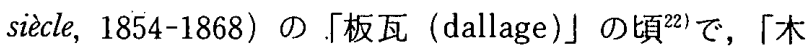
造小屋組をヴォールトに変えようと考えついた時，人は まずモルタル地の上に石の板瓦とか大きな焼瓦を莫き， ヴォールトの外迫を保護しようと思った」と的とし，南仏 などの教会堂によく用いられる有効な方法であると述べ ていることからわかる。

以上のように, ヴィオレ・ル・デュクは確信をもって 後陣祭室の屋根直材を変更したのである。しかし, 彼の

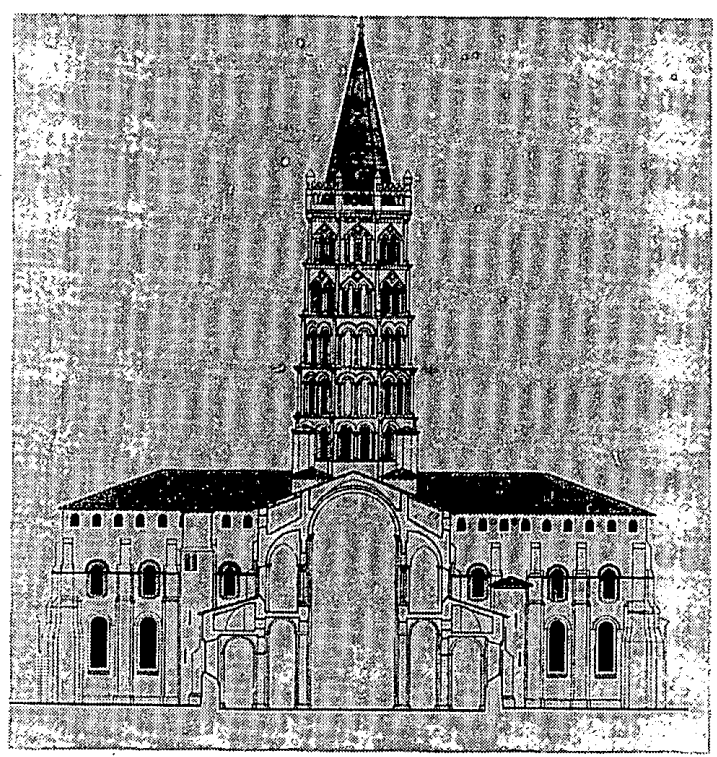

図一6ヴィオレ・ル・デュク介入以前の南北断面図（ボワレに よる)
デザインした屋根は「「カラパス (carapace)」と呼ばれ る亀の背甲のごとく堅固で,ふくれた異様な様相を呈し， さらにガルグイユやアクロテリオンのような屋根飾りを 施したため，ロマネスクの簡素で素朴な後陣とはかけ離 れた印象を与えてしまった。ついでながら，後陣祭室す べてに付設されたガルグイユ付雨樋は，エスキエの復原 によるものであり，それが平瓦屋根の重々しい印象をよ り一層強める結果となった。

一方，身廊とトランセプトの屋根の復原に関しても， 16 世紀の改造で増築された壁を取壊すことについて異 論を唱える人はヴィオレ・ル・デュクの時代にいなかっ た。考古学会もこの増築は単に「ヴォールトの外迫から 屋根を離すため」だけと見なし，「当初の屋根は，ヴォー ルトの上に間隔をとらずに載っていた。．.野地板の湿気 を防ぐため,そして雨漏りが直接ヴォールト天井にしみ こまないように，外壁を高くする必要が出てきて，側壁 を増築したのである。そして，その新しい壁に一連の半 円空を開け,教会堂の周囲全体に巡らせた。…それによっ てヴォールトと新しい屋根との間の採光と換気が確保さ れた。市民戦争の際，これらの窓は砲眼に改造され，そ こに大砲の砲身が現れていたのである」と立とし，増築さ れた側壁の削除に対して，大きな反対もなかったようで ある。しかしここで問題なのは, なぜ現状のように復原 されたのかという点である。

筆者は次のように推測する。

ヴィオレ・ル・デュクは南部考古学会の提案を参考に して,まず16 世紀に増築された側壁を削除する决定を 下し，身榔とトリビューンの屋根を別構造にする承認を 得る。ヴィオレ・ル・デュクはそれに基づいて屋根形式 の復原に取り掛かるが, その際に彼がトゥルーズのサ ン・セルナン教会堂で見いだした比例大系の調和を実現

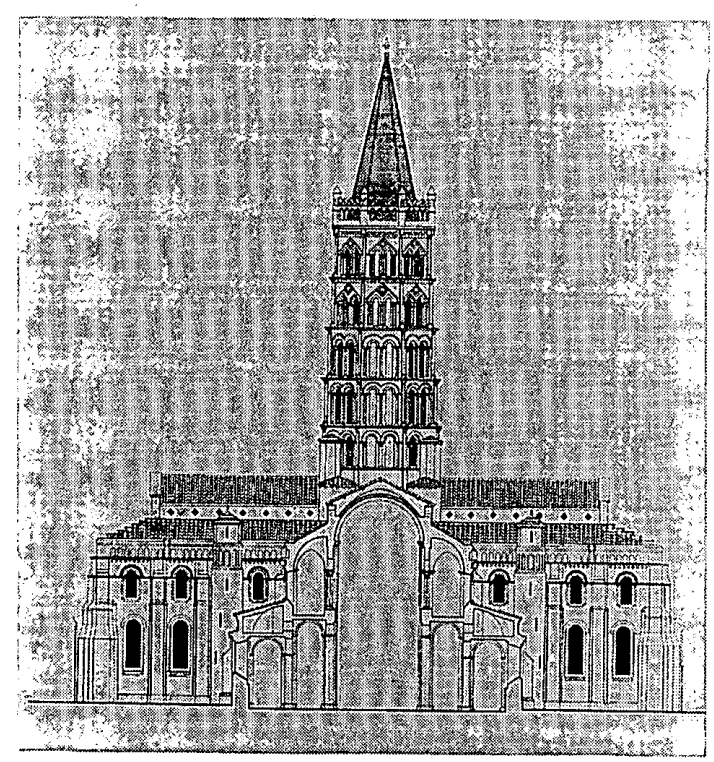

図一7現状の南北断面図（ボワレによる） 
するためにまったくの創作を行ったのである。それは彼 が『中世建築事典」の「比例 (proportion)」の項 ${ }^{25}$ で 述べた次の文章からわかる。

「南仏のトゥルーズのサン・セルナン教会堂は, この ようなギリシア・ローマ的影響の，もっとも完全で生き 生きとした刻印を押された記念建造物のひとつである。 そこには東ローマ帝国のギリシア人たちがローマ式建築 に適用した比例の諸原理が示されている。実際，サン・ セルナン教会堂で用いられた比例の体系は, 内部から外 部へ発出しているのである。そして，その比例大系は正 三角形と直角三角形に基ついている。…の比例大系か ら, サン・セルナン教会堂の建築家は直角三角形と正三 角形の二つの三角形の線上に彼の建築の比例を従属させ たと見なせる。なぜなら，すべての階で目を止める点と いうのは， 45 度と 60 度の傾きをもつ線上にあると考え られるからである(図一8, 図一9)。建物の輪郭は, こ れらの傾きの線上のいかなる点からも外れることはな い ${ }^{26)}$

このように, ヴィオレ・ル・デュクがサン・セルナン 教会堂で感じた調和の秘密は, 外観の全体的規則性と室 内のヴォリューム構成との正確な符合に由来するとし, そのために屋根の形態もトリビューン, 身廊, 1 階側廊 の内部構成をそのまま表出していなければならないと考 えたのである。そして, 外観之室内の比例大系は正三角 形と直角三角形の線上，つまり 45 度と 60 度の傾きをも つ線上に主要な点がなければならないとし，トリビュー

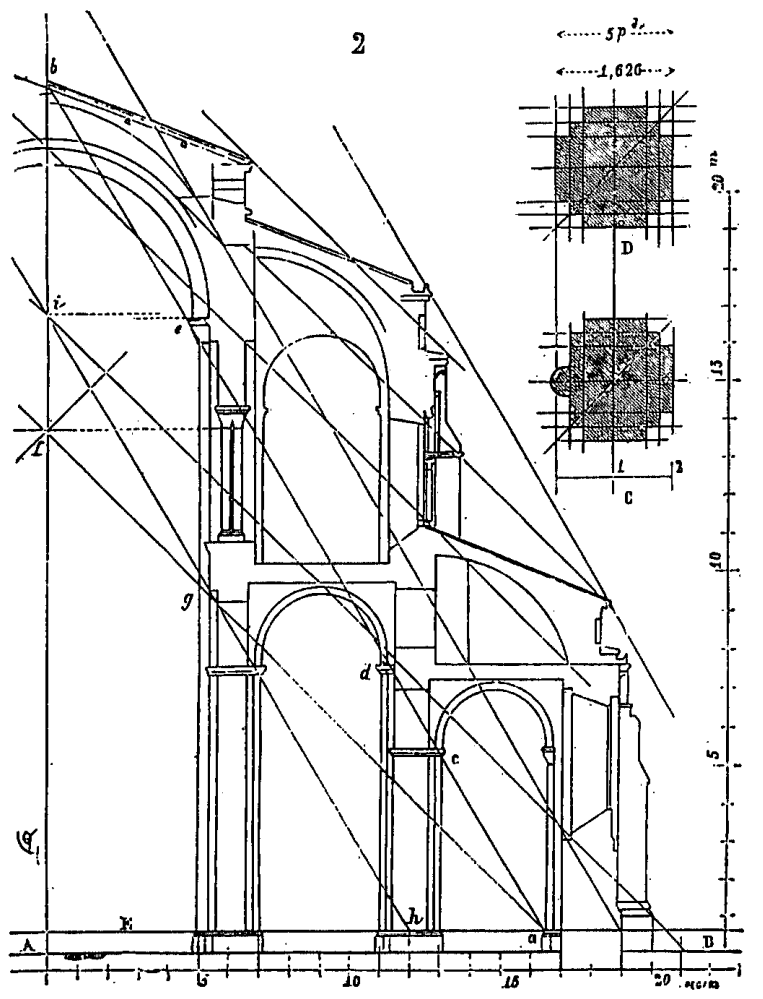

図一8 断面寸法における比例体系 (「中世建築事典」より)
ンと 1 階側廊の軒の位置が決められた。そして身廊の天 井裏に換気と採光のための空を開ける際も，その空の形 態を 45 度の線に沿った菱形とした。トリビューンの屋 根は四分の一円ヴォールトの外迫に沿って勾配が決めら れ，身廊よりも若干急勾配になる。さらに後陣に一部が。 残存していた飾持送の付いた雨桶付コーニスを南北ファ サード全体に復原した。このコーニスは当初からのもの ではなく,16 世紀に付設された後補の雨樋だが, 雨仕 舞のために必要だと判断して復原したのである。それは, ヴィオレ・ル・デュクが『中世建築事典』の「修復 (restauration)」の項 ${ }^{27)}$ で述べている例とよく似ている。

「例えば 12 世紀に建てられ，屋根の軒先に雨樋のない 建物が 13 世紀に修復され，排水溝を含む軒樋が付設さ れることになった。その後壁頂部が全体的に悪い状態に なり，すべてを再建しなければならなくなった。他で兒 られるような 12 世紀の古いコーニスを再び設け，13 世 紀の雨樋を除去するだろうか。確害に否である。12 世 紀の形式を保存しつつ, 13 世紀の軒桶付コーニスを再 建する必要がある」」28

ここで異なる点は 13 世紀の技術的改良がサン・セル ナン教会堂の場合は 16 世紀に行われていたというとこ ろだけである。このようにして，軒樋付コー二スが全体 的に付加されたのである。しかし，トリビューン屋根の 軒先と復原したコーニスとの間に小壁が生じてしまっ た。ヴィオレ・ル・デュクは，計画の段階ではこの間隙 部分に何も手を加えないつもりだった。しかし，実施さ

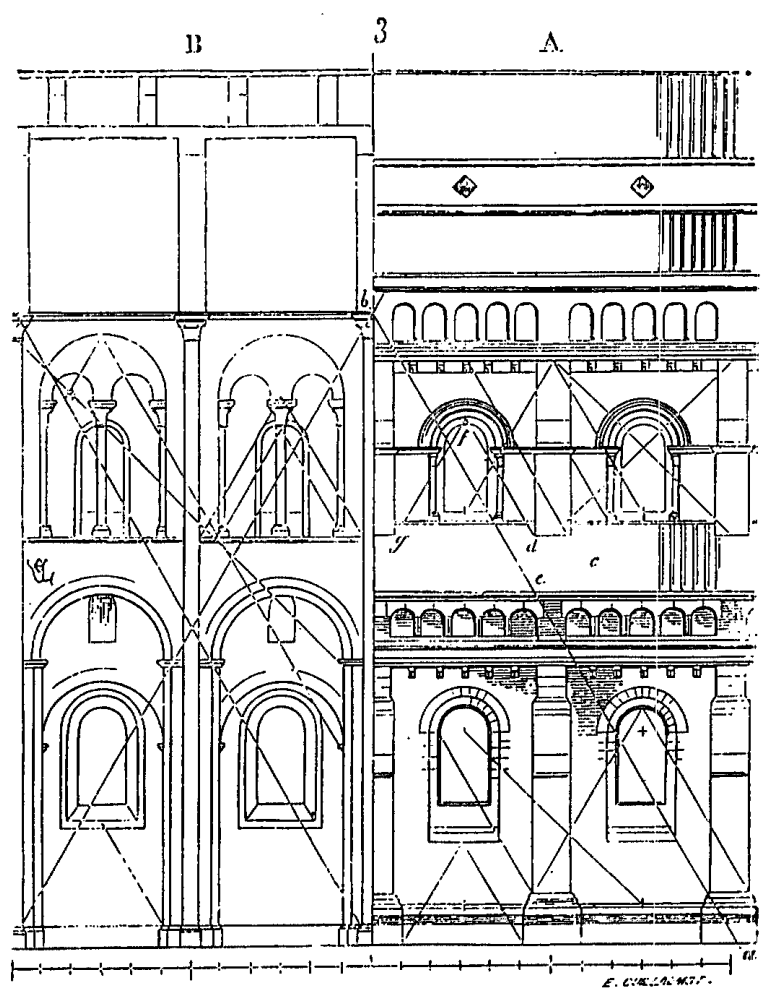

図一9 室内之外観の立面構成における比例体系（『中世建築事 典」より) 


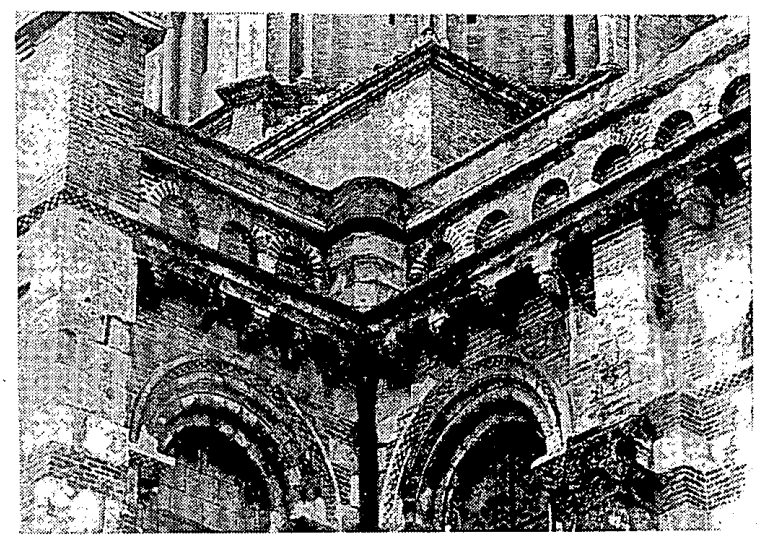

図一10 ヴィオレ・ル・デュクによって創設されたコーニスと ロンバルディア帯

れる段階でロンバルディア帯を全体に入れてしまったの である（図一10)。その結果ロマネスクの簡素で，強健 な外観を大きく変えてしまうことになる。そして身廊と トリビューンの屋根を別構造に分けたことによってトラ ンセプトのファサードの寄棟屋根も切妻と寄棟が混合し た異様な形態にせざるを得なくなってしまった。ヴィオ レ・ル・デュクのこうした復原は明らかに行き過ぎた 「様式統一 (unité de style)」であり，彼が見いだした 比例大系の調和を実現するためになされた蛇足的復原だ といえるのである。

\section{5. 結 語}

ヴィオレ・ル・デュクが修復における最重要の条件と して述べているのは，「取り替え部分はすべて以前のも のより上質な材料と，より効果的，より完全な方法によっ てのみ代用すべきである。…修復後の建物は，それまで 経てきた時間よりも長く，いつまでも立ち続けなければ ならない」吕ということである。それは，材料の交換に おいて以前より上質なものを用いることと，堅牢性を保 証するためには以前からの構造形式を変更しても構わな いということを意味している。また「これらの建設方法 は相対的な価值を持つものであり，必ずしも良質である わけではない。そのうちのいくつかは久陷があり，放棄

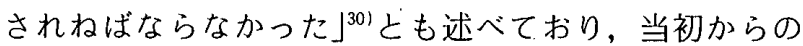
構造形式であっても欠陥のあるものは改善すべきだとし ている。

トゥルーズのサン・セルナン教会堂においてヴィオ レ・ル・デュクは,この修復の基本に従って, 当初材よ り堅固亡思われたカルカソンヌの石を交換材として選 び「いつまでも立ち続けられる」ように，新しい屋根 形式に改善した。しかし，実際にはヴィオレ・ル・デュ クの修復は百年を経て，色あせてしまい，再び修復しな ければならない状況となった。それは，ヴィオレ・ル・ デュク自身が述べているように，修復建築家としてもっ とも恥ずべき結果となってしまったのである。そして，
地方の建築様式，構造，材料に関して深い知識をもつ建 築家が修復に当たるべきだ，という基本を自ら実証した わけである。

\section{注と参考文献}

1) Abbé M.-B. CARRIÈRE, Visite à Saint-Sernin, XLème Congrès Archéologique, Toulouse, p. 403, 1876.

2）イコモス・フランス支部総会が 1980 年 4 月 22 日から 25 日までトゥルーズで開催され，ヴィオレ・ル・デュクを 中心とした 19 世紀の修復をテーマにしたシンポジウムが 行われた。当日発表者が配付した資料のうち本稿に関連 するものは，以下の通りである。 \# Francis SALET, Saint-Sernin de Toulouse.

\# Marcel DURLIAT, Les restaurations monumentales dans la partie occidentale du Languedoc -XIXème et XXème siècles.

\# Yves BOIRET, Les problèmes de restauration à Saint-Sernin de Toulouse (1969-1980)

3) Yves BOIRET, Saint-Sernin de Toulouse : restauration des couronnements et toitures, Icomos information, pp. 3-11, No. 3-1990.

4) Pierre MONJOIN, L'œuvre Toulousaine de VIOLLET LE DUC, Mémoires de la Société Archéologique du Midi de la France, Tome XXV，1957. を主に参照。

5）トゥルーズのサン・セルナン教会堂の沿革については, Francis SALET, op. cit., E. DELARUELLE, SaintSernin, La carte du ciel 21, Zodiaque, La pierre-quivire, 1975.などを参照。

6）側壁を增築した時期については, 南部考古学会はカルヴァ ン派が立てこもる前にすでに採光・換気用に行われたと している。(Monographie de l'insigne basilique de SaintSernin, Toulouse, p. 83, pp.136-137, 1854).

一方ヴィオレ・ル・デュクを補佐した地元の建築家エス キ工は，カルヴァン派の占領時になされた増築だとして いる。(J. ESQUIÉ, Notes sur les travaux de restauration récemment exécutés à l'Églișe Saint-Sernin, Mémoires de l'Académie des Sciences de Toulouse, 1881, p. 294.

7) Prosper MÉRIMÉE, Notes de Voyages (Paris : Librairie Hachette, 1971), pp. 231-236.

8) Ibid., p. 233.

9) Archives des Monuments Historiques, 523, Saint-Sernin (1835-1898).

10) Prosper MÉRIMÉE, Lettre à Vitet, le 21 août, 1845. (Marcel DURLIAT, Toulouse : La restauration de l'église Saint-Sernin, de l'ancien collège Saint-Raymond et $\mathrm{du}$ donjon du Capitole, Catalogue Viollet-le-Duc, p. 105, 1980).

11）エスキエについては，詳細はわからないが，反ボザール 派のデュバンの古い弟子だったことは知られている。そ んなことからヴィオレ・ル・デュクのお気に入りの建築 家だったに違いない。

12) J. ESQUIÉ, Notes sur les travaux de restauration récemment exécutés à l'Église Saint-Sernin, Mémoires de l'Académie des Sciences de Toulouse, 1881. 
13) Ibid, , p. 153.

14)「様々な組合の職人とカルカソンヌ石が南フランス鉄道局 に買占められた。そのために, 大工, 石工, 石切り工, たちが手間賃の值上げを要求しだし，6月一杯はストラ イキまでおきてしまった」(J. ESQUIÉ, op. cit., p.158)

15）拙稿【ヴィオレ・ル・デュクによるトゥルーズのサン・ セルナン教会堂の修復 (その2)」, 日本建築学会大会講 演梗概集 9142，p. 2788，1980，を参照。

16) J. ESQUIÉ, op. cit., p. 157.

17) Yves BOIRET, Les problèmes de restauration à SaintSernin de Toulouse, p.6, (1969-1980).

18）例えば，アンティム・サン・ポールは，「サン・セルナン 教会堂の修復は, ヴィオレ・ル・デュクの作品の中でもっ とも劣悪な例の一つである。なぜなら地方美の要求と慣 習に合わせようとする気遣いがまったくなかったから」 と述べ, 南フランスの建築様式や材料についての無知を 指摘している。(Anthyme Saint-Paul, Viollet-le-Duc. Ses travaux d'art et son système archéologique, Tours, p. 44, 1881).

19）拙稿「ヴィオレ・ル・デュクによるトゥルーズのサン・
セルナン教会堂の修復」，日本建築学会関東支部仾究報告 集, 17, pp.139-140，1980，を参照。

20) Pierre MONJOIN, op. cit., p. 159.

21) Abbé M.-B. CARRIÈRE, op. cit., p. 403.

22) E.E. VIOLLET-LE-DUC, Dictionnaire raisonné de l'architecture française XIème au XVIème siècle, 1854-1868; tome V, pp.9-24, 1861.

23) Ibid., p. 20.

24) Société Archéologique, Monographie de l'insigne basilique de Saint-Sernin, Toulouse, p. 83, pp.136-137, 1854.

25) E.E. VIOLLET-LE.DUC, op. cit., tome VII, pp. 532$561,1864$.

26) Ibid., p. 539-541.

27) E.E. VIOLLET-LE-DUC, op . cit., tome VII, pp. 14$34,1866$.

28) Ibid., p. 24

29) Ibid., p. 26.

30) Ibid., p. 24.

(1990 年 12 月 10 日原稿受理, 1991 年 4 月 10 日抄用决定) 